\title{
CONTINUITY OF CARE PADA NEONATUS DAN BAYI DI ERA PANDEMI COVID-19 DI SUMATERA BARAT
}

\author{
Lusiana El Sinta Bustami ${ }^{1 *}$, Yulizawati ${ }^{2)}$, Erda Mutiara Halida ${ }^{3)}$, Fitrayeni ${ }^{4)}$, Rafika \\ Oktova $^{5)}$, Laila Rahmi ${ }^{6}$, Ulfa Farrah Lisa ${ }^{7)}$, Aldina Ayunda Insani ${ }^{8)}$, Uliy Iffah ${ }^{9)}$, \\ Feni Andriani ${ }^{10)}$, Miranie Safaringga ${ }^{11)}$ \\ ${ }^{1)}$ Fakultas Kedokteran, Universitas Andalas. email: lusianaelsinta@yahoo.co.id \\ ${ }^{2)}$ Fakultas Kedokteran, Universitas Andalas. email: yulizawati@yahoo.co.id \\ ${ }^{3)}$ Fakultas Kedokteran, Universitas Andalas. email: erda_mutiara@yahoo.com \\ ${ }^{4)}$ Fakultas Kedokteran, Universitas Andalas. email: fitrayeni10@gmail.com \\ ${ }^{5)}$ Fakultas Kedokteran, Universitas Andalas. email: rafikamkeb@gmail.com \\ ${ }^{6)}$ Fakultas Kedokteran, Universitas Andalas. email: lailarahmi@med.unand.ac.id \\ ${ }^{7)}$ Fakultas Kedokteran, Universitas Andalas. email: ulfafarrahlisa@med.unand.ac.id \\ ${ }^{8)}$ Fakultas Kedokteran, Universitas Andalas. email: aldinaayundainsani@ymail.com \\ ${ }^{9)}$ Fakultas Kedokteran, Universitas Andalas. email: uliyiffah07@ gmail.com \\ ${ }^{10)}$ Fakultas Kedokteran, Universitas Andalas. email: fenie_mcb89@yahoo.com \\ ${ }^{11)}$ Fakultas Kedokteran, Universitas Andalas. email: miraniesafaringga@gmail.com
}

\begin{abstract}
ABSTRAK
Bayi Baru Lahir dan neonatus memiliki resiko ganggguan kesehatan paling tinggi, berbagai masalah kesehatan bisa muncul, sehingga tanpa penanganan yang tepat, akan memiliki dampak berbahaya pada bayi. Saat ini, Indonesia sedang menghadapi bencana nasional non alam Covid-19 sehingga pelayanan kesehatan maternal dan neonatal menjadi salah satu layanan yang terkena dampak baik secara akses maupun kualitas. Kasus Covid-19 untuk wilayah Sumatera Barat yang masih meningkat dan kasus positif tidak hanya terjadi pada wanita yang sehat, namun juga ada yang tanpa gelaja, wanita hamil, menyusui, bayi baru lahir, anak dan dewasa. Agar ibu dan bayi tetap dapat selalu mendapatkan asuhan selama masa pandemi, maka sebagai bidan dapat dilakukan asuhan kebidanan berkelanjutan (Continuity of care) pada ibu dan keluarga dengan lebih inovatif dengan tetap harus memperhatikan protokol kesehatan dalam memberikan asuhan pada ibu dan bayi. Tujuan yang akan dicapai dalam kegiatan ini adalah meningkatnya angka derajat kesehatan yang lebih baik pada bayi, sehat fisik dan tumbuh serta berkembang secara normal di era pandemi covid-19. Metode yang dipakai dengan melakukan survey dan wawancara untuk pengumpulan data, analisis data, penyajian data, merumuskan pembahasan dan selanjutnya diberikan komunikasi, informasi dan edukasi (KIE) dilakukan dengan metode daring dengan menggunakan aplikasi SMS, video conference, zoom, WA dan aplikasi lainnya.
\end{abstract}

Kata kunci : Bayi Baru Lahir, Neonatus, Covid-19, Continuity of Care

\section{ABSTRACT}

Newborn and neonatus have the highest risk of health problems, various health problems can arise. So that without proper handling, it will have a dangerous impact on the baby. Currently, Indonesia is facing a national non-natural disaster Covid-19 so that maternal and neonatal health services are among the services that are affected both in terms of access and quality. Covid-19 cases for the West Sumatra region are still increasing and positive cases do not only occur in healthy women, but also those who are uneasy, pregnant, breastfeeding, newborns, children and adults. So that mothers and babies can always receive care during the pandemic, as a midwife continuous midwifery care can be carried out for mothers and families more innovatively while still having to pay attention to health protocols in providing care to mothers and babies. The goals in this event that will be achieved are to increase the health status in babies, physically healthy and grow and develop normally in the era of the Covid-19 pandemic. The method used by conducting surveys and interviews for data collection, data analysis, data presentation, formulating discussions and give the education, 
information by online using SMS, video conferencing applications, zoom, WA and other video applications.

Keywords: Newborns, Neonates, Covid-19, Continuity of Care

\section{PENDAHULUAN}

Bencana non alam yang disebabkan oleh Corona Virus atau Covid-19 telah berdampak meningkatnya jumlah korban dan kerugian harta benda, meluasnya cakupan wilayah yang terkena bencana, serta menimbulkan implikasi pada aspek sosial ekonomi yang luas di Indonesia. Dalam situasi normal, kematian ibu dan kematian neonatal di Indonesia masih menjadi tantangan besar, apalagi pada saat situasi bencana. Saat ini, Indonesia sedang menghadapi bencana nasional non alam Covid-19 sehingga pelayanan kesehatan maternal dan neonatal menjadi salah satu layanan yang terkena dampak baik secara akses maupun kualitas (Gugus Tugas Covid-19, 2020)

Bayi Baru Lahir memiliki resiko ganggguan kesehatan paling tinggi, berbagai masalah kesehatan bisa muncul. Sehingga tanpa penanganan yang tepat, biasa berakibat fatal. Faktor penyebab kematian bayi di Indonesia berdasarkan hasil Riset Kesehatan Dasar (Riskesdas) menunjukkan bahwa, penyebab kematian terbanyak pada kelompok bayi 0-6 dominasi oleh gangguan/ kelainan pernafasan $(35,9 \%)$, prematuritas $(32,4 \%)$ dan sepsis (12\%). Dilain pihak faktor ibu yang berkontribusi terhadap lahir mati dan kematian bayi diusia 0-6 hari adalah Hipertensi Maternal (23,6\%), komplikasi kehamilan dan kelahiran $(17,5 \%)$, ketuban pecah dini dan perdarahan antepartum masing-masing (12,5\%). Penyebab utama kematian bayi pada kelompok 7-28 hari yaitu Sepsis (20,5\%), malformasi kongenital $(18,1 \%)$ dan pnemonia $(15,4 \%)$. Dan penyebab utama kematian bayi pada kelompok 29 hari-11 bulan yaitu Diare $(31,4 \%)$, pnemonia $(23,8)$ dan meningitis/ ensefalitis $(9,3 \%)$, sedangkan cakupan $\mathrm{KN} 1$ : 77,31\% (Kemenkes, 2015).

Upaya yang dilakukan pemerintah untuk mengurangi $\mathrm{AKB}$ antara lain seperti ; 1) Meningkatkan Pelayanan kesehatan Neonatal, yaitu dengan mengharuskan agar setiap bayi baru lahir mendapatkan pelayanan Kunjungan Neonatal minimal 3 kali (KN1, KN2 dan KN3) sesuai standar. 2) Penanganan neonatal dengan kelainan atau komplikasi/kegawatdaruratan sesuai standar tenaga kesehatan yang mana pelayanannya antar lain seperti Manajemen Terpadu Bayi Muda (MTBM), Manajemen Asfiksia Bayi Baru Lahir, Manajemen Bayi Berat Lahir Rendah (Kemenkes, 2015).

Agar ibu dan bayi tetap dapat selalu mendapatkan asuhan yang berkesinambungan selama masa pandemi, maka sebagai tenaga kesehatan terutama bidan dapat dilakukan asuhan kebidanan yang berkelanjutan (Continuity of care) pada ibu dan keluarga. Pada masa pandemi ini tenaga kesehatan harus lebih inovatif dalam melaksanakan asuhan kepada keluarga, namun tetap harus memperhatikan protokol kesehatan terkait Covid-19 dalam memberikan asuhan pada ibu dan bayi. Salah 
satu bentuk kegiatan yang dapat dilakukan untuk memberikan asuhan kepada bayi baru lahir dan neonatus tersebut yaitu dengan memberikan informasi berupa komunikasi, informasi dan edukasi (KIE) pada ibu bayi secara daring dengan menggunakan aplikasi yang tersedia saat ini.

Berdasarkan latar belakang di atas, maka tim pengabdian masyarakat dari Prodi Pendidikan profesi bidan melakukan pengabdian masyarakat terkait hal tersebut.

\section{METODE PELAKSANAAN KEGIATAN}

Perencanaan pelaksanaan kegiatan ini dimulai pada bulan Juni 2020 dan dapat terlaksana pada bulan Oktober 2020. Kegiatan dimulai dengan pendataan individu dan keluarga yang akan dijadikan peserta pengabdian masyarakat yaitu dilakukan dengan melakukan wawancara secara online (WA, SMS, telepon, dll), untuk mendapatkan data ini, tim bekerja sama dengan preseptor klinik yang ada di PMB di wilayah Padang, Padang Panjang, dan Padang Pariaman beserta mahasiswa Pendidikan Profesi Bidan.

Dari pendataan yang dilakukan, didapatkan data, lalu dilakukan analisis data, penyajian data, merumuskan pembahasan dan kesimpulan untuk mengatasi permasalahan fokus pada ibu yang memiliki bayi untuk selanjutnya dapat dilakukan asuhan kebidanan berkelanjutan yang bersifat promotif dan preventif menuju bayi yang sehat di masa pandemi Covid-19.

Bentuk kegiatan yang dilakukan adalah pemberian KIE yang dilaksanakan secara daring melalui aplikasi yang tersedia yaitu zoom meeting.

\section{HASIL DAN PEMBAHASAN}

Pelaksanaan kegiatan pengabdian kepada masyarakat ini dilakukan dengan :

1. Hasil pendataan individu dan keluarga dimana ibu yang terdata dan dapat mengukuti pengabdian masyarakat secara online sebanyak 25 orang yang berada di berbagai daerah di wilayah kerja PMB di kota Padang, Padang Pariaman, dan Padang Panjang.

2. Anamnesa pada ibu yang mempunyai bayi serta peran serta suami, keluarga dan masyarakat dan keluhan ibu terhadap kondisi kesehatan bayi saat masa pandemi covid -19

3. Penyuluhan terkait aspek yang terlibat penting dalam kesehatan bayi untuk pencegahan penularan covid-19 dan hal penting dalam kesehatan bayi di era pandemi saat ini, yang secara online dengan aplikasi zoom meeting. Penyuluhan ini dilaksanakan kurang lebih 90 menit.

4. Pelaksanaan pemberian KIE dan penyebaran media KIE kepada ibu dan keluarga terkait kesehatan bayi juga dilakukan dengan penyebaran leaflet secara online dengan menggunakan berbagai aplikasi yang ada.

\section{KESIMPULAN}

1. Kegiatan pengabdian kepada masyarakat yang dilakukan kepada ibu-ibu yang memiliki bayi terlaksana dengan baik dengan dukungan yang diberikan oleh berbagai pihak baik preseptor di PMB 
dan mahasiswa Program Studi

Pendidikan Profesi Bidan serta dari ibuibu yang memiliki bayi di Sumatera Barat.

2. Peran serta aktif masyarakat (ibu-ibu yang memiliki bayi) disertai dengan dukungan oleh Bidan sebagai preseptor lapangan merupakan hal positif yang harus senantiasa dibangun di komunitas sebagai upaya meningkatkan pengetahuan masyarakat dalam mewujudkan masyarakat terutama bayi yang sehat selama masa pandemi Covid19.

3. Terdapatnya peningkatan pengetahuan ibu dan keluarga terkait kesehatan bayi selama masa pandemi Covid -19 sehingga dapat menjaga kesehatan bayi agar selalu sehat.

\section{SARAN}

1. Diharapkan kegiatan pemberian KIE pada masyarakat dapat dilakukan tidak hanya kepada ibu-ibu namun juga kepada ayah dan keluarga yang juga terlibat dalam mengasuh dan membesarkan bayinya, dan kegiatannya dilakukan secara rutin dan terprogram baik oleh bidan pada Praktik Mandiri Bidan sebagai upaya asuhan kebidanan yang berkelanjutan (Continuity of Care).

2. Diharapkan kegiatan promotif dan preventif dapat tetap diselenggarakan baik oleh Bidan atau pun tenaga kesehatan yang melaksanakan program kegiatan Puskesmas selama masa pandemi covid-19 untuk tetap bisa memberikan pelayanan kepada masyarakat dengan menggunakan berbagai aplikasi yang tersedia

3. Diharapkan tenaga kesehatan dapat meningkatkan kreatifitas dan memiliki inovasi dalam menciptakan metode yang efektif dalam memberikan informasi kepada masyarakat, terutama ibu dan bayi agar informasi yang diberikan dapat diterima dan dilaksanakan dengan baik

\section{UCAPAN TERIMAKASIH}

Tim pengabdian masyarakat Prodi Pendidikan Profesi Bidan mengucapkan terima kasih kepada Fakultas Kedokteran Universitas Andalas melalui Unit Penelitian dan Kegiatan Ilmiah (UPKI) yang telah memberikan bantuan dan dukungan, agar kegiatan ini dapat terselengara. Preseptor lapangan, dan mahasiswa yang telah membantu agar kegiatan ini dapat terlaksana dengan baik dan ibu-ibu yang memiliki bayi wilayah Sumatera Barat yang meluangkan waktu, sehingga kegiatan terlaksana dengan baik dan lancar.

\section{REFERENSI}

[1] Gugus Tugas COVID-19. 2020. Pedoman Penanganan Cepat Medis dan Kesehatan Masyarakat COVID-19 Di Indonesia. Gugus Tugas Percepatan Penanganan COVID-19 : Jakarta

[2] Kementerian Kesehatan RI. 2015. InfoDATIN. Pusat Data dan Informasi.

[3] Kementerian Kesehatan RI,. 2020. Pedoman Bagi Ibu Hamil, Bersalin, Nifasm dan Bayi Baru Lahir di Era Pandemi Covid-19. Dirjen Kesehatan Keluarga: Kemenkes RI

[4] Sandall, J. 2017. The Contribution Of Continuity Of Midwifery Care To High Quality Maternity Care. Royal College of Midwives (RCM) 1-11 
[5] Marmi, dkk. Asuhan Neonatus Bayi, Balita, dan Anak Prasekolah. Yogyakarta: Pustaka Pelajar. 2012. Kementerian Kesehatan Republik Indonesia/Kemenkes RI.(c). 2020. Pedoman Bagi Ibu Hamil, Ibu Nifas dan
Bayi Baru Baru Lahir Di Era Pandemi COVID-19. Direktorat Kesehatan Keluarga, Direktorat Jendral Kesehatan Masyarakat Kementerian Kesehatan RI : Jakarta. 